\title{
Modulation of advanced glycation endproducts (AGEs) signaling in experimentally induced stroke in mice.
}

\author{
Amany Yosry, Mohamed Abd-Elaal, Waleed Barakat* \\ Department of Pharmacology and Toxicology, Faculty of Pharmacy, Zagazig University, Egypt. \\ * Corresponding author: Tel: 00201116628 005,E-mail: waleed.barakat@zu.edu.eg \\ Received:2 Aug 2020 /Accepted: 12 Aug 2020 /Published online: 13 Aug 2020
}

\begin{abstract}
Stroke is a leading cause of death and permanent disability in adults worldwide. Advanced glycation endproducts (AGEs) are known to be increased in several chronic diseases and induce inflammation and protein crosslinking.

The current study was designed to investigate the protective effect of benfotiamine, perindopril (at a sub-hypotensive dose), and alagebrium on experimentally induced stroke in mice. All drugs were administered for 9 days starting one week before middle cerebral artery occlusion (MCAO).

Benfotiamine, perindopril and alagebrium ameliorated the deleterious effects of MCAO as indicated by the improvement in the performance of the animals in behavior tests and the reduction in brain infarction. This was associated with normalization of the levels of receptor for advanced glycation end products (RAGE) and its soluble form sRAGE that were changed following MCAO. In addition, benfotiamine, perindopril and alagebrium corrected the upregulation in the downstream effectors TNF- $\alpha$ and VCAM-1.

The results of the current study represent a new indication for benfotiamine, perindopril, alagebrium in the management of ischemic stroke.
\end{abstract}

Keywords: AGEs signaling; benfotiamine; perindopril; alagebrium; MCAO.

Running title: AGEs signaling in experimentally induced stroke.

\section{INTRODUCTION}

Stroke is the second leading cause of death and the most frequent cause of permanent disability in adults worldwide (Barakat, Safwet et al. 2014, Krishnamurthi, Ikeda et al. 2020). Despite advances in understanding the pathophysiology of cerebral ischemia, therapeutic options for acute ischemic stroke remain very limited (Woodruff, Thundyil et al. 2011).

Acute occlusion of a cerebral artery results in hypoxia in the core region of the affected brain tissue, followed by a series of inflammatory reactions causing further cell death and functional deficits (Eltzschig and Eckle 2011).

Accumulation of advanced glycation endproducts (AGEs) and protein crosslinking occurs with ageing and hyperglycemia (Bucala, Makita et al. 1994) and they are implicated in diabetic complications (Hammes, Wellensiek et al. 1998).

The receptor for advanced glycation end products (RAGE) is implicated in various disorders (Kalea, Schmidt et al. 2009). Binding of RAGE to AGEs, high mobility group box 1 (HMGB1), and S100 protein (Kim, Hudson et al. 2005) leads to activation of inflammatory pathways, cytokine production, generation of reactive oxygen intermediates, and nuclear factor $-\kappa \mathrm{B}$ activation (Lotze and Tracey 2005).

Soluble isoform of RAGE (sRAGE) can function as a decoy to compete with RAGE for ligand binding and consequently blocks RAGE-associated intracellular signaling 
(Kalea, Schmidt et al. 2009) and injury (Aida, Kamide et al. 2019).

This study aims to investigate the effects of some drugs that modulate AGEs signaling as the synthetic derivative of thiamine, benfotiamine that blocks AGEs formation (Balakumar, Rohilla et al. 2010), the centrally active angiotensin-converting enzyme inhibitor, perindopril (Yamada, Uchida et al. 2010) (at a sub-hypotensive dose) that increases the plasma level of sRAGE (Forbes, Thorpe et al. 2005) and the AGEs crosslink breaker alagebrium chloride (ALT-711) (Vaitkevicius, Lane et al. 2001, Toprak and Yigitaslan 2019).

\section{Materials and methods}

\subsection{Animals}

Balb C mice (18-24 g) purchased from Theodor Bilharz Research Center, Cairo, Egypt were used in all experiments. The mice were kept under standard environmental and nutritional conditions throughout the investigation. All experimental procedures were approved by the Ethical Committee for Animal Handling at Zagazig University (ECAHZU).

Mice were randomly distributed into 5 groups $(\mathrm{n}=10)$ as follows: Sham operated mice, Ischemic mice, Ischemic mice treated with benfotiamine $(70 \mathrm{mg} / \mathrm{kg} /$ day)(Katare, Caporali et al. 2010), perindopril at a nonhypotensive dose (1 $\mathrm{mg} / \mathrm{kg} /$ day)(Min, Kobayashi et al. 2017), or alagebrium (2 $\mathrm{mg} / \mathrm{kg} /$ day).(Park, Kwon et al. 2011). All drugs were administered for 9 days starting one week before middle cerebral artery occlusion (MCAO) as reported previously using other drugs on MCAO model (Guo, Wang et al. 2009, Park, Jang et al. 2010).

\subsection{Induction of ischemia}

Middle cerebral artery occlusion, (MCAO) was performed according to the method described previously (Barakat, Herrmann et al. 2009).

\subsection{Behavioral test}

Motor coordination (Bederson, Pitts et al. 1986), and sensorimotor deficit using the corner test (Zhang, Schallert et al. 2002) were assessed.

\subsection{Determination of the infarct volume by Hematoxylin and Eosin staining}

After $48 \mathrm{~h}$, animals were anesthetized, and perfused with $50 \mathrm{ml}$ Ringer's solution through the heart. The brain was carefully isolated then stored at $-80{ }^{\circ} \mathrm{C}$. $20 \mu \mathrm{m}$ sections were prepared using cryostat (SLEE, Mainz, Germany). The whole brain was cut from olfactory bulb to the cerebellum. The distance between sections was $400 \mu \mathrm{m}$. Brain sections were used for the determination of infarct volume using $\mathrm{H}$ $\&$ E staining as described previously (Aras, Guven et al. 2015). The remaining brain tissue was homogenized and extracted using phosphate buffered saline and used for the determination of brain tumor necrosis factor-alpha (TNF- $\alpha$ ) and vascular cell adhesion molecule 1 (VCAM-1).

\subsection{Determination of different biochemical parameters}

Serum RAGE level was determined using ELISA kits supplied by RayBiotech, Inc., sRAGE was detected using ELISA kits supplied by AVISCERA BIOSCIENCE INC., TNF- $\alpha$ level was detected using ELISA kits supplied by RayBiotech, Inc. and VCAM level was detected using ELISA kits supplied by RayBiotech, Inc.

\subsection{Statistical analysis}

Data are expressed as mean \pm standard error of the mean. Statistical analysis was performed using one way analysis of variance (ANOVA) followed by Tukey's post Hoc test using Graph pad Prism 
software version 5. For all analysis, the level of statistical significance was set at $\mathrm{p}<0.05$.

\section{Results}

\subsection{Effect of MCAO and treatment with benfotiamine, perindopril and} alagebrium on behavior:

Fig. 1 shows that MCAO caused a significant increase in neurological score, while treatment with benfotiamine, perindopril and alagebrium caused a significant reduction in neurological scores compared with ischemic group reaching $0.98,0.82$ and 0.93 vs 3.4 respectively (Fig. 1a).

In the corner test, animals subjected to MCAO showed a significant increase in the percentage of right turns reaching 95.3 in ischemic day 1 vs 50.3 and 97.5 in ischemic day 2 vs 49.6 compared with the same mice prior to MCAO. Administration of benfotiamine, perindopril and alagebrium significantly decreased the percentage of right turns in day 1 reaching 67.5, 61.5 and 63 vs 95.3 respectively compared to ischemic mice day 1 and 65.5, 58.5 and 60.7 vs 97.5 respectively compared to ischemic day 2 (Fig. 1b).

3.2 Effect of MCAO and treatment with benfotiamine, perindopril and alagebrium on infarct volume:

Mice subjected to MCAO showed brain infarct. Treatment with benfotiamine, perindopril and alagebrium significantly decreased the infarct volume compared to the ischemic group reaching 13.5, 10.8 and 11.8 vs 23.8 respectively as shown in Fig. 2.

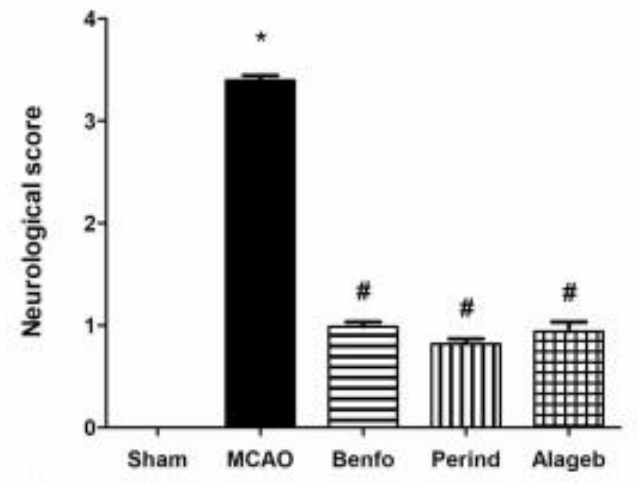

a)

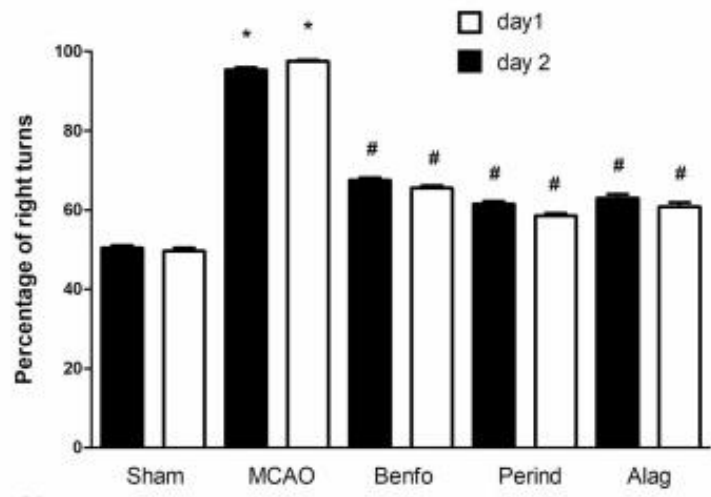

b)

Fig.1: Effect of MCAO and treatment with benfotiamine, perindopril and alagebrium on a) Neurological score, and b) Performance in the corner test. Data are expressed as mean \pm S.E.M., $n=10$. * Significantly different from the sham group, \# Significantly different from MCAO group at $P<0.05$ using ANOVA followed by Tukey's post Hoc test.

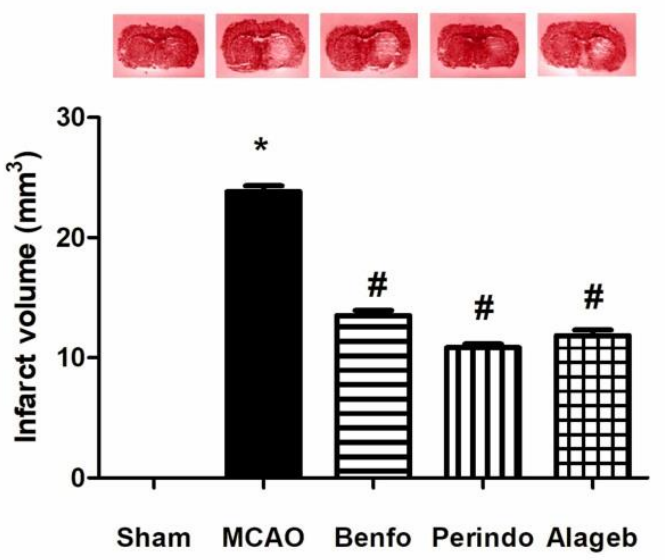

Fig 2: Effect of MCAO and treatment with benfotiamine, perindopril and alagebrium on infarct volume. Data are expressed as mean \pm S.E.M., $n=10$.

* Significantly different from the sham group, \# Significantly different from MCAO group at $P<0.05$ using ANOVA followed by Tukey's post Hoc test. 
Zagazig J. Pharm. Sci. Dec, 2020

Vol. 29, Issue 2, pp. 1-10

3.3 Effect of MCAO and treatment with benfotiamine, perindopril and alagebrium on RAGE and SRAGE:

After MCAO, the level of RAGE and sRAGE was significantly increased reaching 76.6 vs 14.1 and 80.5 vs 15.1 respectively compared to sham group, while treatment with benfotiamine, perindopril and alagebrium caused a significant decrease in RAGE and sRAGE level compared to the ischemic group reaching 20.9, 18.2 and 16 vs 76.6 and $22.1,19.8$ and 17.1 vs 80.5 respectively as shown in Fig. 3 a \& b.
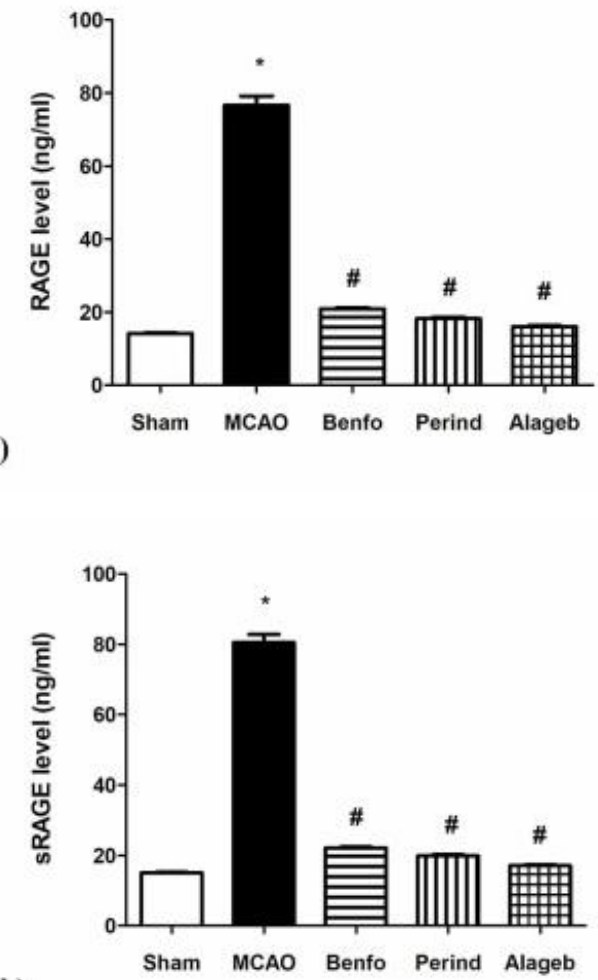

b)

Fig 3: Effect of MCAO and treatment with benfotiamine, alagebrium, perindopril on: a) RAGE b) sRAGE. Data are expressed as mean \pm S.E.M, $n=10$. * Significantly different from the sham group, \# Significantly different from MCAO group at $P<0.05$ using ANOVA followed by Tukey's post Hoc test.

3.4 Effect of MCAO and treatment with benfotiamine, perindopril and alagebrium on TNF- $\alpha$ and VCAM-1:

MCAO caused a significant increase in TNF- $\alpha$ and VCAM-1 reaching 57.5 vs 9.3
ISSN 1110-5089

ISSN (on-line) 2356_9786

$\mathrm{pg} / \mathrm{ml}$ and 7.2 vs $1 \mathrm{ng} / \mathrm{ml}$ respectively compared to sham group, while treatment with benfotiamine, perindopril and alagebrium caused a significant decrease in TNF- $\alpha$ and VCAM-1 level compared to the ischemic group reaching 18.1, 11.8 and 15.1 vs $57.5 \mathrm{pg} / \mathrm{ml}$ and 2, 1.7 and 1.4 vs 7.2 $\mathrm{ng} / \mathrm{ml}$ respectively as shown in Fig. $4 \mathrm{a} \& \mathrm{~b}$.
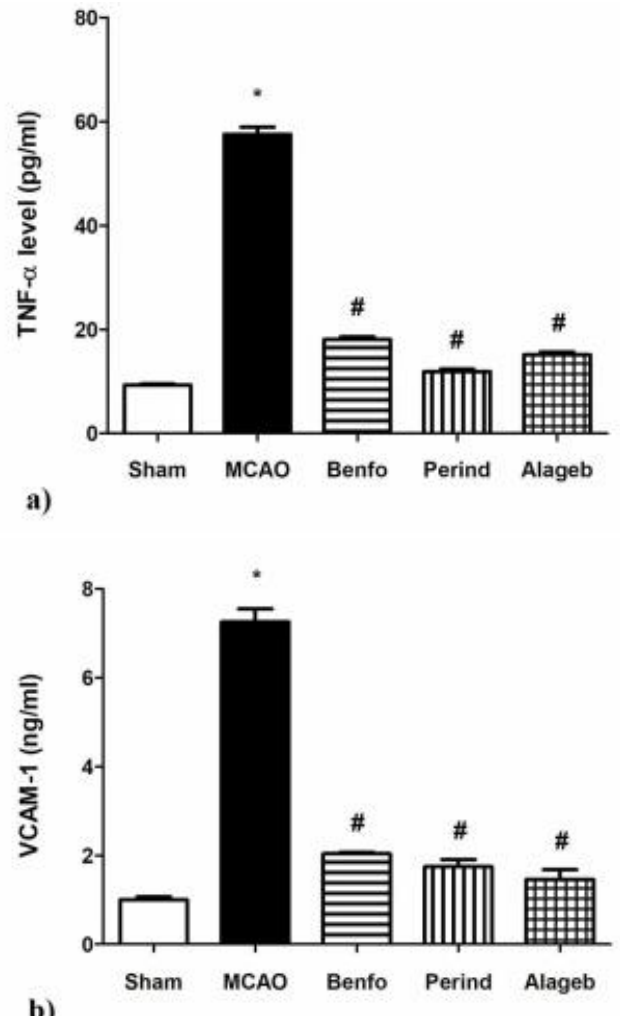

Fig 4: Effect of MCAO and treatment with benfotiamine, alagebrium and perindopril on: a) TNF- $\alpha$ and b) VCAM-1. Data are expressed as mean \pm S.E.M, $n=10$. * Significantly different from the sham group, \# Significantly different from MCAO group at $P<0.05$ using ANOVA followed by Tukey's post Hoc test.

\section{Discussion}

Stroke is a leading cause of death and disability worldwide (Katan and Luft 2018, Krishnamurthi, Ikeda et al. 2020).

Cerebral ischemia is followed by a strong inflammatory response (Kong and Le 2011) characterized by release of cytokines and adhesion molecules that aggravate ischemic brain injury (Caso, Pradillo et al. 2007). 
The generation of advanced glycation endproducts (AGEs) occurs with normal aging and is enhanced by oxidative stress, acute inflammatory stimuli (Ramasamy, Vannucci et al. 2005) and prolonged hyperglycemia which contribute to diabetic complications (Thomas, Baynes et al. 2005).

The current study aimed to study the potential neuroprotective effect of agents that modulate AGEs signaling against ischemic brain injury induced in mice by MCAO.

In the present study, MCAO but not sham was associated with neurological deficits as evidenced by the increased neurological score and the increased percentage of right turns in the corner test. In addition, MCAO-induced infarction in the brain tissue. Similar deleterious effects of MCAO were previously shown (Chiang, Messing et al. 2011, Barakat, Safwet et al. 2014).

Treatment with benfotiamine, perindopril or alagebrium was associated with an improvement in the behavioral changes induced by MCAO and a reduction in the infarct size.

In the present study, MCAO was associated with an elevated level of RAGE and sRAGE compared to sham group indicating the involvement of AGE signaling in the pathophysiological events following ischemia.

We have previously shown the elevation of AGEs following MCAO in mice (Yosry, Abd-Elaal et al. 2017). Also, previous studies have shown that, brain AGEs are increased during normal aging and in Alzheimer's dementia (Bar, Franke et al. 2003). AGEs were shown to be neurotoxic to cultured neurons (Takeuchi, Bucala et al. 2000) and mediate migration of inflammatory cells (Ramasamy, Vannucci et al. 2005). Expression of the receptor for advanced glycation endproducts (RAGE) was increased following brain ischemia (Aida, Kamide et al. 2019) and was shown to mediate neuroinflammation and ischemic injury (Greco, Demartini et al. 2017, Ye, Zeng et al. 2019). In addition, deletion of RAGE improved neuronal survival after brain ischemia (Aida, Kamide et al. 2019).

sRAGE acts as a decoy for RAGE that protects cells against RAGE-mediated injury (Aida, Kamide et al. 2019). Serum level of sRAGE is increased in stroke patients (Tang, Yang et al. 2017, Ye, Zeng et al. 2019) and overexpression of sRAGE improved neuronal survival after brain ischemia (Aida, Kamide et al. 2019).

We have previously shown that blocking RAGE signaling using sRAGE, a neutralizing anti-HMGB1 antibody, or the HMGB1 antagonist box A was effective against both inflammation and delayed cell death in stroke (Muhammad, Barakat et al. 2008).

In the current study, using benfotiamine, perindopril or alagebrium was shown to ameliorate the changes in RAGE and sRAGE induced by MCAO.

Benfotiamine, perindopril or alagebrium were previously shown to ameliorate the elevated AGEs following MCAO (Yosry, Abd-Elaal et al. 2017). Benfotiamine was shown to reduce AGEs formation (Nagai,Shirakawa et al. 2014) and reduce diabetic vascular complications (Bozic, Savic et al. 2015). ACE inhibition by perindopril was shown to reduce accumulation of AGEs, increase sRAGE (Forbes, Thorpe et al. 2005) and reduce oxidative stress and RAGE activation in rats (Goel, Bhat et al. 2016). Although perindopril was previously shown to increase sRAGE (Forbes, Thorpe et al. 
2005) in diabetic patients, however, in the current study similar action was not shown which might be attributed to the difference in disease model, species and dose administered.

In addition, MCAO was associated with an increase in the inflammatory mediator TNF- $\alpha$ and VCAM-1.

Following stroke, the level inflammatory cytokines as tumor necrosis factor is increased (Liu, Clark et al. 1994, Lambertsen, Biber et al. 2012). This is associated with impaired expression of adhesion molecules including vascular cell adhesion molecule-1 (VCAM-1) (Libby, Sukhova et al. 1995). VCAM-1 is a proinflammatory mediator that is increased by IL- $1 \beta$ and TNF- $\alpha$ in stroke (Jin, Liu et al. 2013), leading to recruitment of leukocytes (Libby, Sukhova et al. 1995). Elevated VCAM-1 was reported in stroke patients (Supanc, Biloglav et al. 2011) and blocking VCAM-1 improved neurological deficits and decreased neuronal death (Zhang and Wei 2003).

Treatment with benfotiamine, perindopril or alagebrium was able to reduce TNF- $\alpha$ and VCAM- 1 to near control values.

Benfotiamine has demonstrated antiinflammatory activity in vitro (Bozic, Savic et al. 2015) and was shown to modulate NF$\kappa \mathrm{B}$ and vascular endothelial growth factor receptor 2 (VEGFR2) signaling pathways (Raj, Ojha et al. 2018). The protective effect observed following perindopril administration might be attributed to its antiinflammatory action and modulation of RAGE and sRAGE levels.

Perindopril is a centrally active angiotensin-converting enzyme inhibitor (Yamada, Uchida et al. 2010). Previous studies have demonstrated the increase in angiotensin II type-1 (AT1) receptor following stroke (Edvinsson 2008) and the protective effect of angiotensin receptor blockers (ARBs) in animal stroke models (Mecca, O'Connor et al. 2009). The protective effect observed following perindopril administration might be attributed to its anti-inflammatory action and modulation of RAGE level.

We have previously demonstrated the effectiveness of candesartan (angiotensin receptor blocker) in the management of ischemic stroke through their antiinflammatory action (Barakat, Safwet et al. 2014). In addition, perindopril was shown to reduce vascular markers of inflammation VCAM-1 (Lu, Ke et al. 2008, Vaccari, Rahman et al. 2008).

\section{Conclusion}

The current study showed the role of AGEs signaling in ischemic brain injury induced in mice by MCAO as evidenced by the elevation in RAGE and SRAGE which was accompanied by an increase in the inflammatory mediator TNF- $\alpha$ and VCAM1. Interestingly, modulation of AGEs signaling by benfotiamine, perindopril or alagebrium was successful in ameliorating these deleterious effects induced by MCAO and the accompanied neurological deficits.

\section{Author contribution:}

MA and WB designed the research, AY performed the animal experiments, AY and WB analyzed the data and wrote the manuscript, MA revised the manuscript.

\section{Conflict of interest:}

The authors wish to confirm that there are no known conflicts of interest associated with this publication and there has been no significant financial support for this work that could have influenced its outcome.

Also, the authors confirm that all data were generated in-house and that no paper mill was used. 
Zagazig J. Pharm. Sci. Dec, 2020

Vol. 29, Issue 2, pp. 1-10

\section{REFERENCES}

Aida, Y., T. Kamide, H. Ishii, Y. Kitao, N. Uchiyama, M. Nakada and O. Hori (2019). "Soluble receptor for advanced glycation end products as a biomarker of symptomatic vasospasm in subarachnoid hemorrhage." J Neurosurg: 1-9.

Aras, A. B., M. Guven, T. Akman, A. Ozkan, H. M. Sen, U. Duz, Y. Kalkan, C. Silan and M. Cosar (2015). "Neuroprotective effects of daidzein on focal cerebral ischemia injury in rats." Neural Regen Res 10(1): 146-152.

Balakumar, P., A. Rohilla, P. Krishan, P. Solairaj and A. Thangathirupathi (2010). "The multifaceted therapeutic potential of benfotiamine." Pharmacol Res 61(6): 482488.

Bar, K. J., S. Franke, B. Wenda, S. Muller, R. Kientsch-Engel, G. Stein and H. Sauer (2003). "Pentosidine and N(epsilon)(carboxymethyl)-lysine in Alzheimer's disease and vascular dementia." Neurobiol Aging 24(2): 333-338.

Barakat, W., O. Herrmann, B. Baumann and M. Schwaninger (2009). "NF-kappaB induces PGE2-synthesizing enzymes in neurons." Naunyn Schmiedebergs Arch Pharmacol 380(2): 153-160.

Barakat, W., N. Safwet, N. N. El-Maraghy and M. N. Zakaria (2014). "Candesartan and glycyrrhizin ameliorate ischemic brain damage through downregulation of the TLR signaling cascade." Eur J Pharmacol 724: 43-50.

Bederson, J. B., L. H. Pitts, M. Tsuji, M. C. Nishimura, R. L. Davis and H. Bartkowski (1986). "Rat middle cerebral artery occlusion: evaluation of the model and development of a neurologic examination." Stroke 17(3): 472-476.

Bozic, I., D. Savic, D. Laketa, I. Bjelobaba, I. Milenkovic, S. Pekovic, N. Nedeljkovic and I. Lavrnja (2015). "Benfotiamine attenuates inflammatory response in LPS stimulated BV-2 microglia." PLoS One 10(2): e0118372.

Bucala, R., Z. Makita, G. Vega, S. Grundy, T. Koschinsky, A. Cerami and H. Vlassara (1994). "Modification of low density lipoprotein by advanced glycation end products contributes to the dyslipidemia of
ISSN 1110-5089

ISSN (on-line) 2356_9786

diabetes and renal insufficiency." Proc Natl Acad Sci U S A 91(20): 9441-9445.

Caso, J. R., J. M. Pradillo, O. Hurtado, P. Lorenzo, M. A. Moro and I. Lizasoain (2007). "Toll-like receptor 4 is involved in brain damage and inflammation after experimental stroke." Circulation 115(12): 1599-1608.

Chiang, T., R. O. Messing and W. H. Chou (2011). "Mouse model of middle cerebral artery occlusion." J Vis Exp(48).

Edvinsson, L. (2008). "Cerebrovascular angiotensin AT1 receptor regulation in cerebral ischemia." Trends Cardiovasc Med 18(3): 98-103.

Eltzschig, H. K. and T. Eckle (2011). "Ischemia and reperfusion--from mechanism to translation." Nat Med 17(11): 1391-1401.

Forbes, J. M., S. R. Thorpe, V. Thallas-Bonke, J. Pete, M. C. Thomas, E. R. Deemer, S. Bassal, A. El-Osta, D. M. Long, S. Panagiotopoulos, G. Jerums, T. M. Osicka and M. E. Cooper (2005). "Modulation of soluble receptor for advanced glycation end products by angiotensin-converting enzyme-1 inhibition in diabetic nephropathy." J Am Soc Nephrol 16(8): 2363-2372.

Goel, R., S. A. Bhat, K. Hanif, C. Nath and R. Shukla (2016). "Perindopril Attenuates Lipopolysaccharide-Induced

Amyloidogenesis and Memory Impairment by Suppression of Oxidative Stress and RAGE Activation." ACS Chem Neurosci 7(2): 206-217.

Greco, R., C. Demartini, A. M. Zanaboni, F. Blandini, D. Amantea and C. Tassorelli (2017). "Modulation of cerebral RAGE expression following nitric oxide synthase inhibition in rats subjected to focal cerebral ischemia." Eur J Pharmacol 800: 16-22.

Guo, Q., G. Wang, X. Liu and S. Namura (2009). "Effects of gemfibrozil on outcome after permanent middle cerebral artery occlusion in mice." Brain Res 1279: 121130.

Hammes, H. P., B. Wellensiek, I. Kloting, E. Sickel, R. G. Bretzel and M. Brownlee (1998). "The relationship of glycaemic level to advanced glycation end-product (AGE) accumulation and retinal pathology in the 
spontaneous diabetic hamster." Diabetologia 41(2): 165-170.

Jin, R., L. Liu, S. Zhang, A. Nanda and G. Li (2013). "Role of inflammation and its mediators in acute ischemic stroke." J Cardiovasc Transl Res 6(5): 834-851.

Kalea, A. Z., A. M. Schmidt and B. I. Hudson (2009). "RAGE: a novel biological and genetic marker for vascular disease." Clin Sci (Lond) 116(8): 621-637.

Katan, M. and A. Luft (2018). "Global Burden of Stroke." Semin Neurol 38(2): 208-211.

Katare, R. G., A. Caporali, A. Oikawa, M. Meloni, C. Emanueli and P. Madeddu (2010). "Vitamin B1 analog benfotiamine prevents diabetes-induced diastolic dysfunction and heart failure through Akt/Pim-1-mediated survival pathway." Circ Heart Fail 3(2): 294305.

Kim, W., B. I. Hudson, B. Moser, J. Guo, L. L. Rong, Y. Lu, W. Qu, E. Lalla, S. Lerner, Y. Chen, S. S. Yan, V. D'Agati, Y. Naka, R. Ramasamy, K. Herold, S. F. Yan and A. M. Schmidt (2005). "Receptor for advanced glycation end products and its ligands: a journey from the complications of diabetes to its pathogenesis." Ann N Y Acad Sci 1043: 553-561.

Kong, Y. and Y. Le (2011). "Toll-like receptors in inflammation of the central nervous system." International Immunopharmacology 11(10): 1407-1414.

Krishnamurthi, R. V., T. Ikeda and V. L. Feigin (2020). "Global, Regional and CountrySpecific Burden of Ischaemic Stroke, Intracerebral Haemorrhage and Subarachnoid Haemorrhage: A Systematic Analysis of the Global Burden of Disease Study 2017." Neuroepidemiology 54(2): 171-179.

Lambertsen, K. L., K. Biber and B. Finsen (2012). "Inflammatory cytokines in experimental and human stroke." J Cereb Blood Flow Metab 32(9): 1677-1698.

Libby, P., G. Sukhova, R. T. Lee and Z. S. Galis (1995). "Cytokines regulate vascular functions related to stability of the atherosclerotic plaque." I Cardiovasc Pharmacol 25 Suppl 2: S9-12.

Liu, T., R. K. Clark, P. C. McDonnell, P. R. Young, R. F. White, F. C. Barone and G. Z.
Feuerstein (1994). "Tumor necrosis factoralpha expression in ischemic neurons." Stroke 25(7): 1481-1488.

Lotze, M. T. and K. J. Tracey (2005). "Highmobility group box 1 protein (HMGB1): nuclear weapon in the immune arsenal." Nat Rev Immunol 5(4): 331-342.

Lu, Q., Y. N. Ke, W. L. Cheng, Y. Wang, C. A. Yu and J. Y. Wen (2008). "[Effects of perindopril and enalapril on atherosclerosis development of apolipoprotein $\mathrm{E}$ knockout mice]." Zhonghua Xin Xue Guan Bing Za Zhi 36(4): 350-354.

Mecca, A. P., T. E. O'Connor, M. J. Katovich and C. Sumners (2009). "Candesartan pretreatment is cerebroprotective in a rat model of endothelin-1-induced middle cerebral artery occlusion." Exp Physiol 94(8): 937-946.

Min, L. J., Y. Kobayashi, M. Mogi, K. Tsukuda, A. Yamada, K. Yamauchi, F. Abe, J. Iwanami, J. Z. Xiao and M. Horiuchi (2017). "Administration of bovine casein-derived peptide prevents cognitive decline in Alzheimer disease model mice." PLoS One 12(2): e0171515.

Muhammad, S., W. Barakat, S. Stoyanov, S. Murikinati, H. Yang, K. J. Tracey, M. Bendszus, G. Rossetti, P. P. Nawroth, A. Bierhaus and M. Schwaninger (2008). "The HMGB1 receptor RAGE mediates ischemic brain damage." J Neurosci 28(46): 1202312031.

Nagai, R., J. Shirakawa, R. Ohno, N. Moroishi and M. Nagai (2014). "Inhibition of AGEs formation by natural products." Amino Acids 46(2): 261-266.

Park, J., M. K. Kwon, J. Y. Huh, W. J. Choi, L. S. Jeong, R. Nagai, W. Y. Kim, J. Kim, G. T. Lee, H. B. Lee and H. Ha (2011). "Renoprotective antioxidant effect of alagebrium in experimental diabetes." Nephrol Dial Transplant 26(11): 3474-3484.

Park, S. I., D. K. Jang, Y. M. Han, Y. Y. Sunwoo, M. S. Park, Y. A. Chung, L. S. Maeng, R. Im, M. W. Kim, S. S. Jeun and K. S. Jang (2010). "Effect of combination therapy with sodium ozagrel and panax ginseng on transient cerebral ischemia model in rats." Biotechnol 2010: 893401. 
Zagazig J. Pharm. Sci. Dec, 2020

Vol. 29, Issue 2, pp. 1-10

Raj, V., S. Ojha, F. C. Howarth, P. D. Belur and S. B. Subramanya (2018). "Therapeutic potential of benfotiamine and its molecular targets." Eur Rev Med Pharmacol Sci 22(10): 3261-3273.

Ramasamy, R., S. J. Vannucci, S. S. Yan, K. Herold, S. F. Yan and A. M. Schmidt (2005). "Advanced glycation end products and RAGE: a common thread in aging, diabetes, neurodegeneration, and inflammation." Glycobiology 15(7): 16R-28R.

Supanc, V., Z. Biloglav, V. B. Kes and V. Demarin (2011). "Role of cell adhesion molecules in acute ischemic stroke." Ann Saudi Med 31(4): 365-370.

Takeuchi, M., R. Bucala, T. Suzuki, T. Ohkubo, M. Yamazaki, T. Koike, Y. Kameda and Z. Makita (2000). "Neurotoxicity of advanced glycation end-products for cultured cortical neurons." J Neuropathol Exp Neurol 59(12): 1094-1105.

Tang, S. C., K. C. Yang, C. J. Hu, H. Y. Chiou, C. C. Wu and J. S. Jeng (2017). "Elevated Plasma Level of Soluble Form of RAGE in Ischemic Stroke Patients with Dementia." Neuromolecular Med 19(4): 579-583.

Thomas, M. C., J. W. Baynes, S. R. Thorpe and M. E. Cooper (2005). "The role of AGEs and AGE inhibitors in diabetic cardiovascular disease." Curr Drug Targets 6(4): 453-474.

Toprak, C. and S. Yigitaslan (2019). "Alagebrium and Complications of Diabetes Mellitus." Eurasian J Med 51(3): 285-292.

Vaccari, C. S., S. T. Rahman, Q. A. Khan, F. A. Cheema and B. V. Khan (2008). "Effects of angiotensin-converting enzyme inhibitor therapy on levels of inflammatory markers in response to exercise-induced stress: studies in the metabolic syndrome." J Cardiometab Syndr 3(1): 12-17.

Vaitkevicius, P. V., M. Lane, H. Spurgeon, D. K. Ingram, G. S. Roth, J. J. Egan, S. Vasan, D. R.
ISSN 1110-5089

ISSN (on-line) 2356_9786

Wagle, P. Ulrich, M. Brines, J. P. Wuerth, A. Cerami and E. G. Lakatta (2001). "A crosslink breaker has sustained effects on arterial and ventricular properties in older rhesus monkeys." Proc Natl Acad Sci U S A 98(3): 1171-1175.

Woodruff, T. M., J. Thundyil, S. C. Tang, C. G. Sobey, S. M. Taylor and T. V. Arumugam (2011). "Pathophysiology, treatment, and animal and cellular models of human ischemic stroke." Mol Neurodegener 6(1): 11.

Yamada, K., S. Uchida, S. Takahashi, M. Takayama, Y. Nagata, N. Suzuki, S. Shirakura and T. Kanda (2010). "Effect of a centrally active angiotensin-converting enzyme inhibitor, perindopril, on cognitive performance in a mouse model of Alzheimer's disease." Brain Res 1352: 176186.

Ye, Y., Z. Zeng, T. Jin, H. Zhang, X. Xiong and L. $\mathrm{Gu}$ (2019). "The Role of High Mobility Group Box 1 in Ischemic Stroke." Front Cell Neurosci 13: 127.

Yosry, A., M. Abd-Elaal and W. Barakat (2017). "The possible role of advanced glycation endproducts (AGEs) in experimentallyinduced ischemic brain damage." Zagazig J. Pharm. Sci. 26(2): 78 - 86.

Zhang, L., T. Schallert, Z. G. Zhang, Q. Jiang, P. Arniego, Q. Li, M. Lu and M. Chopp (2002). "A test for detecting long-term sensorimotor dysfunction in the mouse after focal cerebral ischemia." J Neurosci Methods 117(2): 207-214.

Zhang, L. H. and E. Q. Wei (2003). "Neuroprotective effect of ONO-1078, a leukotriene receptor antagonist, on transient global cerebral ischemia in rats." Acta Pharmacol Sin 24(12): 1241-1247. 


\section{تعديل مسار نواتج الجليكُاشن المنظورة (ايه جي إي اس) في السكتة الدماغية المحدثة تجريبيا في الفئران

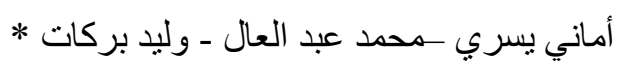$$
\text { قسم علم الأدوية و السموم - كلية الصيدلة - جامعة الزقازيق }
$$

إن السكتة الدماغية هي سبب رئيسي للوفاة وللإعاقة الدائمة لدى البالغين عالميا.

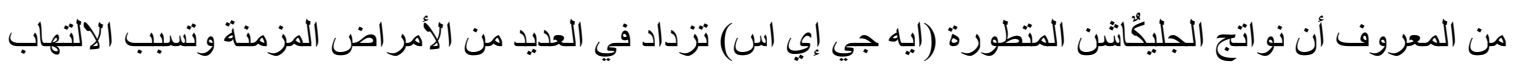
و وتشابك البروتين.

تم تصميم الدراسة الحالية للتحقيق في التأثير الوقائي للبنفوتيامين، البيرندوبريل (بجر عة اقل من المخفضة للضغط)،

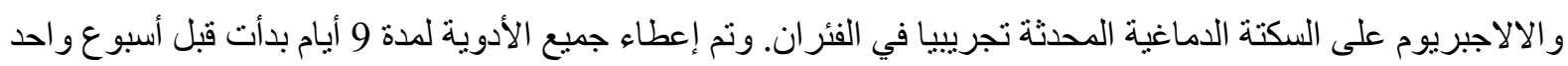
من انسداد الثريان الدماغي الأوسط (ام سي ايه الوائه ). خفف البنفوتامين، البيريندوبريل و الالاجبريوم من التأثيرات الضارة للام سي ايه او كما اتضح من التحسن في أداء الحيو انات في اختبار ات السلوك و انخفاض احتشاء الدماغ. وقد صاحب هذا تعديل في مستويات ار ايه جي اي واس ار ايه جي اي الى المستوى الطبيعي بعد ان تغيرت بسبب الام سي ايه اي. بالإضافة إلى ذللك، قام البنفوتامين، البيريندوبريل

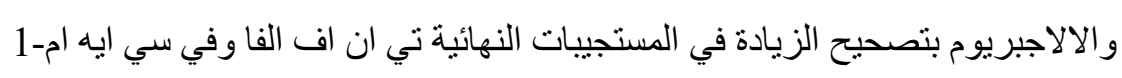

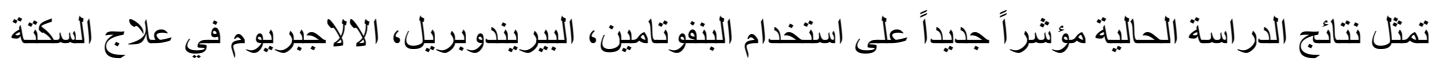

